УДК 330.342 .3

DOI: https://doi.org/10.37320/2415-3583/8.5

Заінчковська М.М. студентка,

Національний технічний університет України «Київський політехнічний інститут імені Ігоря Сікорського»

Корогодова О.O.

кандидат економічних наук, доцент кафедри міжнародної економіки, Національний технічний університет Украйни «Київський політехнічний інститут імені Ігоря Сікорського»

\title{
ВПЛИВ ТРАНСНАЦІОНАЛЬНИХ КОМПАНІЙ НА РОЗВИТОК ЕМЕРДЖЕНТНИХ ЕКОНОМІК (НА ПРИКЛАДІ РЕСПУБЛІКИ КОРЁ̈)
}

\begin{abstract}
У статті розглянуто внесок транснаціональних компаній у розвиток емерджентних країн. Приділено увагу особливостям та відмінностям транснаціональних компаній, щңо розвивалися в емерджентних економіках. На прикладі Республіки Кореї показано, наскільки ТНК впливають на розвиток та спеціалізацію економіки краӥни походження. Акиентовано увагу на чинниках, завдяки яким Республіка Корея зараз має значний рівень економічного розвитку. Зазначено важливість та значимість таких факторів, як тип економіки Республіки Кореї та сочіально-психологічні особливості місиевого населення. Проаналізовано динаміку економічного розвитку Республіки Кореї. Розглянуто «корейський» тип транснаціональних корпорацій, а саме чеболі. Висвітлено історичні та економічні передумови виникнення чеболів. Досліджено еволючію розвитку чеболів, періоди росту та занепаду. Визначено та показано роль чеболів в «економічному диві» Республіки Кореї. У проиесі дослідження розглянуто прочес формування та розвитку, сферу діяльності та вплив на світову економіку найбільшої ТНК Республіки Кореї, а саме "Samsung”. Розглянуто зміну спеціалізації "Samsung” з 1938 року. Висвітлено основні етапи розвитку, оцінено сучасний стан зазначеної транснаціональної корпорачї. Надано характеристику напрямів діяльності “Samsung”. Розглянуто, визначено фактори, завдяки яким “Samsung” стала успішною та диверсифікованою корпоращією. В результаті проведеного аналізу визначено головні причини стрімкого економічного зростання Республіки Кореї. Виявлено важливість окремих факторів в економічному зростанні Республіки Кореї. Досліджено специфіку емерджентних краӥн. Підсумовано головні особливості та відмінності емерджентних економік та компаній, щзо здійснюють виробничу діяльність на теренах таких краӥн.
\end{abstract}

Ключові слова: емерджентні краӥни, ТНК, транснаціональні корпорації, чеболі, Республіка Корея.

Постановка проблеми. За останні десятиріччя структури транснаціонального типу підприємництва посіли значне місце у світовому виробництві товарів та послуг. Нині у світі налічується більше 82 тис. ТНК 3810 тис. філіалів по всьому світі. Штаб-квартири транснаціональних компаній спочатку базувались у розвинутих країнах, які створювали виробничі підрозділи у країнах зі значно нижчим рівнем соціально-економічного розвитку. На перетині XX - XXI століть спостерігається процес перетворення національних компаній на потужні міжнародні корпорації саме в економіках країн, що розвиваються. До останніх також належать країни з емерджентною економікою. Одним 3 яскравих прикладів $є$ Республіка Корея, тобто країна, що 60 років тому була фактично зруйнована внаслідок війни. Проте її уряд вибрав національну стратегію, яка охопила найбільш результативні напрями розвитку, що привело до стрімкого зростання показників ВВП. Це дало змогу посісти високе місце в рейтингу країн - експортерів високих технологій та значно підвищити рівень економічного добробуту населення. Весь світ знає таких корейських економічних велетнів, як "Samsung", "LG Group", "Hyundai".
Аналіз останніх досліджень і публікацій. Дослідження шляху розвитку емерджентних економік проводили такі науковці, як В. Соловйов [1], А. Рус-Полтавська [2], Г. Яценко [3], О. Саліхова [4]. Внесок іноземних технологій у розвиток економіки Республіки Кореї розглядається у джерелі [5]. Дослідження відмінностей транснаціональних корпорацій, що сформувалися в емерджентних економіках, висвітлено у роботі [6]. Представляє інтерес дослідження впливу транснаціональних структур на емерджентний розвиток економіки Республіки Кореї.

Мета статті полягає в розгляді можливостей впливу транснаціональних компаній на розвиток емерджентних економік (на прикладі Республіки Кореї). Відповідно до вибраної мети завданнями $\epsilon$ дослідження загальних особливостей та відмінностей ТНК в емерджентних економіках; оцінювання впливу чеболів на розвиток економіки Республіки Кореї; аналізування напрямів діяльності та рівня впливу на світовий економічний простір найбільшої ТНК Республіки Кореї, а саме "Samsung". Використано такі методи, як аналіз, синтез, узагальнення, порівняння, індукція та дедукція. 
Виклад основного матеріалу. Емерджентними економіками називають економіки, які менш диверсифіковані, рівень заощаджень у яких нижчий, а національні фінансові системи - менш розвинені [7]. Головна особливість емерджентних економік полягає у стрімкому економічному розвитку за рахунок внеску великих компаній та впливу соціального фактору. Соціальна свідомість $€$ характерною рисою населення таких країн, адже вона полягає в тому, що окрема особистість ставить національні та загальнодержавні досягнення вище власних економічних інтересів. Таким чином, у короткостроковій перспективі люди погоджуються отримувати менше доходів заради того, щоби досягти значного рівня економічного зростання у довгостроковій перспективі. Така ситуація має місце за великої довіри керівним органам країни.

ТНК у таких країнах $є$ великими частинами одного цілого та сфокусовані на досягнення однієї стратегічної загальнодержавної мети. Як правило, емерджентні економіки $є$ країнами базування для транснаціональних корпорацій, які розпочинають там свою діяльність, а в майбутньому, досягнувши значних результатів, все одно мають велику частку виробництва саме в материнській країні. Здебільшого стрімкий розвиток емерджентних країн безпосередньо пов'язаний з використанням новітніх технологій, отже, ТНК, що утворюються в таких умовах, мають високотехнологічну спеціалізацію виробництва (робототехніка, електроніка, машинобудування та IT).

Яскравим прикладом емерджентних систем $€$ економіки деяких азійських країн, таких як Республіка Корея та Сінгапур. Ці країни мають японський змішаний тип економіки. Урядові органи та більшість компаній використовують низку специфічних принципів та методів, заснованих на особливостях менталітету. Зазначимо, що такі методи не приводять до схожих результатів в інших національних моделях економічних систем.

В азійських країнах поширеним напрямом стратегій управління компаній $\epsilon$ розвиток власної промисловості шляхом залучення технологій ТНК. Стратегічні рішення, якими скористалися ці країни [8], поділяють на дві категорії, такі як автономні стратегії та стратегії залежності. Стратегія залежності полягає у заохоченні прямих іноземних інвестицій (ПІІ) та значній залежності національної економіки від інших країн, оскільки іноземні інвестори часто мають контрольний пакет акцій певних компаній.

Натомість автономна стратегія полягає в поступовому нарощуванні власних потужностей національних компаній. Метою цієї стратегії є підвищення рівня ВВП у країні, досягнення позитивних показників у сферах торгівлі, фінансів, освіти, у навчанні, технологіях та зрушеннях промисло- вої структури [4]. У рамках цієї стратегії активно залучаються іноземні технології та ПІІ, проте на рівні законодавства є обмеження щодо заборони отримання контрольного пакета акцій іноземним інвестором. Одночасно впроваджується політика стимулювання експорту та розширення впливу власних компаній на міжнародний ринок. Яскравими прикладами успішної реалізації цієї стратегії є економіки Республіка Корея та Тайвань.

ТНК, що сформувались у таких країнах, мають певні характеристики, що виокремлюють їх серед інших структур.

1) Велика частка виробництва припадає на країну базування, збільшуючи у цій країні рівень надходжень від податків, витрат на науку та кількість робочих місць.

2) ТНК має прямий і досить сильний вплив на уряд, відповідно, на законодавство країни базування, оскільки такі компанії створюють значну частину національного продукту країни.

3) Система стимулювання працівників спирається на національну свідомість та патріотизм.

ТНК, що утворилися в емерджентних економіках, $є$ більш пристосованими до змін та швидше адаптуються до зміни навколишнього середовища, ніж ті, що утворились у стабільних економіках. Також такі ТНК мають високий рівень інноваційного розвитку та скорості реагування на тенденції та вектори ринків попиту й пропозиції товарів.

Республіка Корея $є$ унікальною країною 3 точки зору економічного зростання. Це країна, яка 50 років тому була бідною аграрною країною, а зараз $є$ однією з найрозвиненіших країн у галузі високих технологій, а найголовніше, вона не зупиняється у своєму розвитку [9]. За 1960-2010 роки ВВП на душу населення за паритетом купівельної спроможності зріс у 25 разів (рис. 1), а сьогодні складає 36,6 тис. дол. [10]. Зараз Корея - це високорозвинена країна, член «Великої двадцятки», 11 економіка світу за розміром. Досвід Кореї часто наводиться як приклад успішного втручання держави в економіку [6].

Після Корейської війни (1950-1953 роки) економічний розвиток як Південної, так і Північної Кореї був низьким: промисловість була у занепаді, люди жили за межею бідності. Зазначимо, що Корейський півострів бідний на корисні копалини. Проте завдяки певним факторам Республіка Корея змогла забезпечити стрімкий рівень економічного зростання.

Найбільший вплив на розвиток економіки мали такі фактори:

- залучення іноземного капіталу та отримання допомоги з боку США;

- значний ступінь державного втручання в економіку, п’ятирічні завдання;

- залучення до масштабного виробництва багатих та відомих «сімейних родів», тобто чебо- 


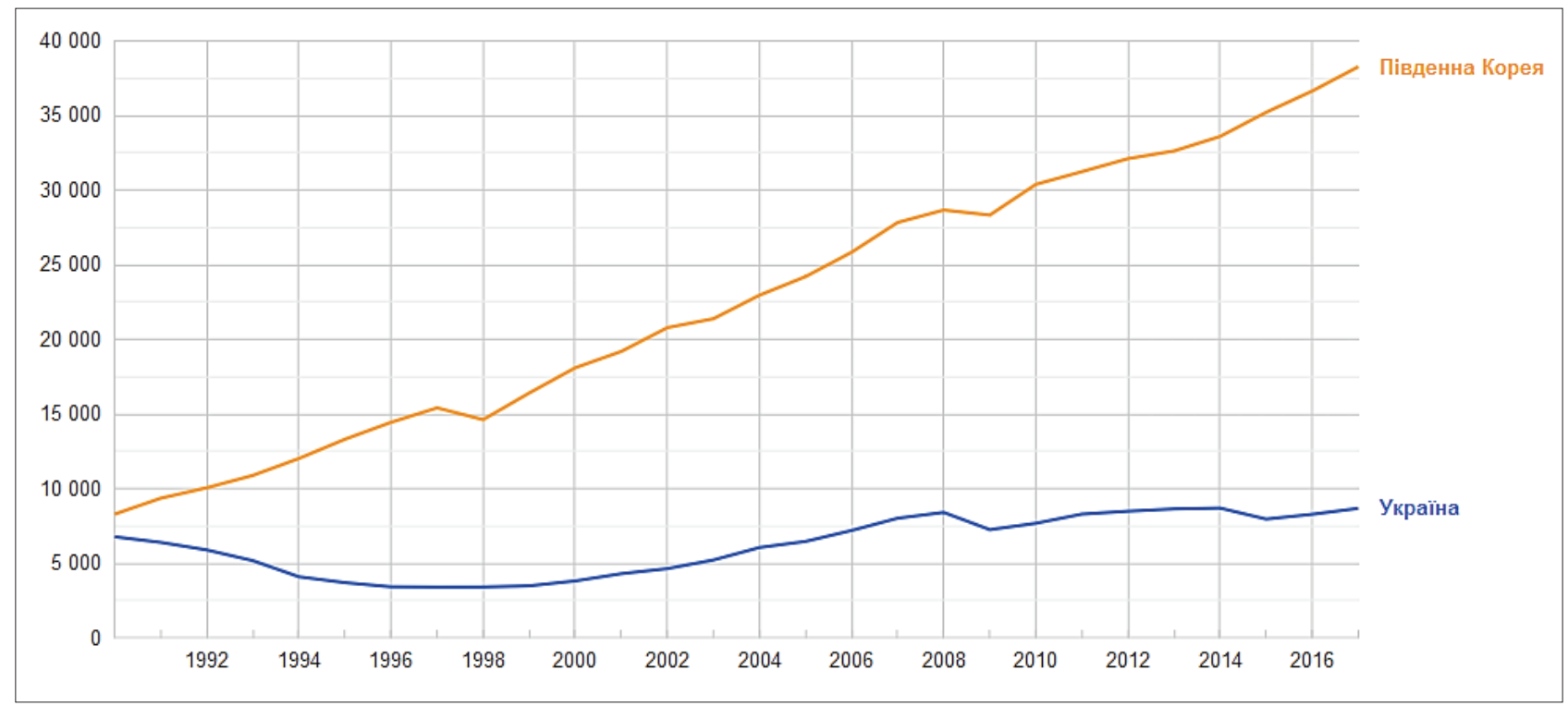

Рисунок 1 - Порівняльна динаміка зміни ВВП за паритетом купівельної спроможності на душу населення у 1990-2017 роках в Україні та Республіці Кореї

Джерело: побудовано авторами за джерелом [10]

лів, які створювали великі компанії у прогресивних галузях, що з часом перетворились на ТНК;

- політика протекціонізму, тобто вжиття заходів щодо обмеження імпорту (діяла протягом 1960-1980 років), стимулювання експорту, тобто надання субсидій та низько відсоткових кредитів для підприємств, що ведуть експортну діяльність;

- значне зростання якості робочої сили через розвиток освіти, охорони здоров'я, соціального захисту;

- значні капіталовкладення в інфраструктуру та переробну промисловість, зменшення частки сільського господарства.

Суттєвим і вагомим є внесок чеболів у розвиток економіки Кореї. Чеболь - це об'єднання формально самостійних компаній, що перебувають у власності певних родів (сімей) під одним адміністративним та фінансовим контролем. Формування статутного капіталу чеболів припало на 60-70-ті роки минулого століття, коли відбулась активна модернізація економіки країни. Саме утворення та розвиток чеболів були рушійними силами до економічного стрибка, відомого у всьому світі, як «економічне диво Республіки Кореї». Зараз у Кореї понад 30 чеболів, найбільшими з яких є "Samsung", "LG", "Lotte", "Hyundai" [7; 9].

Чеболі утворювались у прогресивних сферах економіки, пов'язаних з промисловістю та новими технологіями. Такі компанії працювали за великої державної підтримки та впроваджували у життя п'ятирічні завдання. Саме ці фактори привели до того, що власники чеболів мають значний вплив на уряд країни, отже, досить часто ці компанії лобіюють свої інтереси.

Більшість чеболів зараз $є$ відомими у світі ТНК, проте головною їхньою особливістю є збереження національних рис в умовах транснаціоналізації [5]. Так, "Samsung” у своїй системі мотивації працівників використовує ім'я бренду та особливість відданості працівників компанії [11]. Крім цього, чеболі, як правило, мають вертикальну ієрархічну структуру, яка історично склалась у національній економіці. Чеболі в Республіці Кореї генерують велику частину ВВП, сплачують значний обсяг податків у бюджет країни та надають робочі місця для мільярдів корейців. Крім того, саме такі компанії підвищують рівень іміджу країни на світовому ринку. Чеболі $є$ невід'ємною частиною корейської економіки. Найбільшими й найвідомішими ТНК Республіки Кореї є "Samsung", "LG”, "Нyundai". Ці компанії мають світове ім'я та $€$ гігантами 3 виробництва й продажів електроніки та автомобілів.

У більшості споживачів продукція компаніï "Samsung" асоціюється 3 надійністю, якістю, зручністю та функціональністю. Компанія пройшла довгий шлях для того, щоби проєктувати такі асоціації. Свою історію "Samsung" починає у 1938 році з невеликої приватної фірми, що експортувала харчові товари до Китаю [11]. У післявоєнні роки уряд Республіки Кореї вирішив орієнтуватись на роботу великих компаній для стабілізації економіки, реалізація такої політики відбулася шляхом кредитування перспективних бізнес-гравців країни, що дало можливість підприємствам вирости до великих конгломератів. 
За задумом уряду кожна велика компанія мала відповідати за певний сектор економіки. Так, "Samsung" почав спеціалізуватись на електроніці [11]. Сьогодні більше 70\% продажів "Samsung" припадає на електронну промисловість (“Samsung Electronics", "Samsung SDI", "Samsung Networks", "Samsung SDS", "Samsung Electromechanics") та виробництво побутової техніки.

Крім зазначених підрозділів, діяльність транснаціональної компанії представлена підприємствами хімічної промисловості ("Samsung Total Petrochemicals", "Samsung Petrochemicals", "Samsung Fine Chemicals", "Samsung BP Chemicals"), фінансово-страховими структурами [11]. Флагманська діяльність транснаціональної корпорації також представлена продукцією підрозділу "Samsung Heavy Industries", який займається переважно інноваційним високотехнологічним суднобудуванням та авіабудуванням [12]. Зараз "Samsung" є однією з найбільших промислових транснаціональних компаній у світі, що за типом об'єднання підприємств є концерном. У табл. 1 наведено основні показники діяльності транснаціональної компанії.

Вищезазначені дані проаналізовані авторами за допомогою таких індексів:

1) Індекс транснаціоналізації компанії (формула 1), що розроблений UNCTAD для оцінювання масштабів втручання ТНК в економіки інших країн. Показник використовується для оцінювання значущості закордонної діяльності компаній та важливості розміщення закордонних підрозділів на іноземних ринках для тієї чи іншої ТНК. Чим вище індекс, тим більше значення для компанії має активність іï закордонних філій, дочірніх та асоційованих компаній.

$$
T N I=\frac{\left(\frac{F A}{T A}+\frac{F S}{T S}+\frac{F E}{T E}\right)}{3} * 100 \% .
$$

2) Індекс інтернаціоналізації, що демонструє відношення кількості закордонних підрозділів до загальної кількості підрозділів (формула 2).

$$
I I=\left(\frac{F A F}{T A F}\right) * 100 \% .
$$

3) Індекс широти філіальної мережі, що показує кількість країн, у яких є закордонні підрозділи, до кількості країн, які приймають прямі іноземні інвестиції [7] (формула 3).

$$
N S I=\frac{N}{N-1} * 100 \% .
$$

У табл. 2 наведено розрахунки за формулами (1), (2), (3) для компанії "Samsung Electronics" протягом 2015-2017 років.

В останнє десятиріччя компанія перманентно збільшує рівень отриманого прибутку, кількість та якість активів. Аналізуючи отримані значення індексу транснаціоналізації, бачимо, що у компанії цей показник досить високий, але спостерігається тенденція до поступового збільшення саме корейських активів, тому можна це трактувати як ознаки політики певного протекціонізму та захисту власного виробництва. Отже, компанія "Samsung" займає велику частку світового ринку електроніки (11\%), є найбільшою корпорацією на ринку Республіки Кореї та здійснює значний внесок в економічний розвиток країни.

Висновки. Таким чином, процес розвитку транснаціональних компаній в емерджентних економіках має певні відмінності від розвитку ТНК у розвинутих економіках. Структури транснаціо-

Таблиця 1- Основні показники діяльності "Samsung" за 2015-2017 роки

\begin{tabular}{|l|c|c|c|}
\hline \multicolumn{1}{|c|}{ Показник } & $\mathbf{2 0 1 5}$ рік & $\mathbf{2 0 1 6}$ рік & $\mathbf{2 0 1 7}$ рік \\
\hline Всього співробітників (осіб) & 325,677 & 308,745 & 320671 \\
\hline Співробітників у Кореї (осіб) & 96,902 & 93,204 & 198065692 \\
\hline Продажі (\$) & 175078466 & 186977351 & 25748540 \\
\hline Продажі по Кореї (\$) & 20656747 & 23757927 & 265000000000 \\
\hline Загальні активи (\$) & 230657746000 & 256756835000 & 39758456000 \\
\hline Активи в Кореї (\$) & 35656645000 & 37645764000 & 206 у 68 країнах \\
\hline Всі філії (одиниць) & 206 у 68 країнах & 206 у 68 країнах & 9 \\
\hline Філії в Кореї (одиниць) & 9 & 9 & \\
\hline
\end{tabular}

Джерело: побудовано авторами за джерелом [12]

Таблиця 2 - Розрахунки за формулами (1), (2), (3) для компанії "Samsung Electronics" протягом 2015-2017 років

\begin{tabular}{|l|c|c|c|}
\hline \multicolumn{1}{|c|}{ Показник } & $\mathbf{2 0 1 5}$ рік & $\mathbf{2 0 1 6}$ рік & 2017 рік \\
\hline $\mathbf{I}_{\text {транснаціонал }}$ & 0,810 & 0,808 & 0,806 \\
\hline $\mathbf{I}_{\text {інтернаціонал }}$ & 0,956 & 0,956 & 0,956 \\
\hline $\mathbf{I}_{\text {шир філ. мер. }}$ & 0,347 & 0,347 & 0,347 \\
\hline
\end{tabular}

Джерело: розраховано авторами 
нального типу підприємництва Республіки Кореї $\epsilon$ великими конгломератами, що були створені зі значною допомогою державного капіталу в повоєнні роки та представлені у всіх стратегічно важливих галузях виробництва. На чолі таких ТНК стоять певні визначні сім'ї (чеболі). Зазначені компанії досі мають великий вплив на економіку країни, виконуючи важливі соціальні та економічні функції. Саме завдяки успішному розвитку чеболів у Республіці Кореї спостерігається стійкий рівень економічного зростання. Зазначимо, що саме присутність такого явища, як чеболі, в економіці Республіки Кореї $є$ вагомим фактором національного «економічного дива».

Міжнародна корпорація "Samsung" $є$ найбільшою південнокорейською ТНК, що забезпечує $11 \%$ світового ринку електроніки, має численні підрозділи у різних сферах виробництва. Зараз компанія має представництва, дочірні компанії, асоційовані компанії, виробничі потужності та інші типи підрозділів по всьому світі, проте великий відсоток виробництва досі припадає на країну базування, що забезпечує населення робочими місцями, наповнює бюджет країни податками та підвищує рівень ВВП Республіки Кореї.

Отже, ТНК є визначним фактором розвитку емерджентних країн, оскільки завдяки діяльності зазначених підприємницьких структур уряди можуть впроваджувати ефективні загальнодержавні стратегії. Водночас саме державна підтримка на певному етапі розвитку компаній допомагає завойовувати нові ринки. Розвиток емерджентності в національній економіці країни потребує наявності адекватного інструментарію та відповідного ресурсного забезпечення її імплементації. Зазначений напрям дослідження вважається авторами перспективним та буде докладно розглянутий у подальшому процесі наукового пошуку.

\section{Список використаних джерел:}

1. Емерджентні методи для емерджентної економіки : монографія / за заг. ред. В. Соловйова. Черкаси : видавець Вовчок О.Ю., 2017. 324 с.

2. Рус-Полтавська А. Ключовий фактор у реалізації завдань емерджентної економіки. Держава та регіони. Серія: Економіка та підприємництво. 2016. Вип. 6. С. 10-14.

3. Яценко Г. Інноваційний розвиток країн емерджентного типу. Економіст. 2012. Вип. 8. С. $23-38$.

4. Саліхова О., Бак Г. Стратегії азійських країн з розбудови національної промисловості через залучення технологій ТНК. Зовнішня торгівля: економіка, фінанси, право. 2014. Вип. 3. С. 30-40.

5. Саліхова О., Бак Г. Роль іноземних технологій в інвестиційно-інноваційній модернізації економіки: досвід Республіки Корея, уроки для України. Економіка і прогнозування. 2015. Вип. 1. С. 105-120.

6. Ефремов В., Владимирова И. Особенности транснационализации компаний Южной Кореи. Инновации и инвестиции. 2017. Вип. 2. С. 27-34.

7. IMF Staff Reports for the G-20 Mutual Assessment Process. International Monetary Fund. URL: http://www.imf.org/ external/np/g20/pdf/110411.pdf (дата звернення: 01.11.2019).

8. Investment and Technology Policies for Competitiveness: Review of Successful Country Experiences. United Nations Conference on Trade and Development. URL: https://unctad.org/en/Docs/iteipc20032_en.pdf (дата звернення: 05.11.2019).

9. Південна Корея: справжні причини грандіозного зростання. Vox Ukraine. URL: https://voxukraine.org/uk/pivdennakoreya-spravzhni-prichini-grandioznogo-zrostannya (дата звернення: 11.11.2019).

10. Undata: the world of information. URL: http://data.un.org (дата звернення: 03.11.2019).

11. Офіційний сайт Samsung. URL: https://www.samsung.com/us/aboutsamsung/home (дата звернення: 08.11.2019).

12. Офіційний сайт Samsung Heavy Industries. URL: http://www.samsungshi.com/Eng/Company/info_overview.aspx (дата звернення: 13.11.2019).

\section{References:}

1. Solovjov, V. (2017), Emerdzhentni metody dlia emerdzhentnoi ekonomiky [Emergent Methods for Emergent Economy]. Vovchok O.Yu, Cherkasy, Ukraine.

2. Rus-Poltavs'ka, A. (2016), “Kliuchovyj faktor u realizatsii zavdan' emerdzhentnoi ekonomiky”, Derzhava ta rehiony, vol. 6, pp. 10-14.

3. Yatsenko, H. (2012), "Innovatsijnyj rozvytok krain emerdzhentnoho typu”. Ekonomist, vol. 8, pp. $23-38$.

4. Salikhova, O. and Bak, H. (2014), “Stratehii azijs'kykh krain z rozbudovy natsional'noi promyslovosti cherez zaluchennia tekhnolohij TNK", Zovnishnia torhivlia: ekonomika, finansy, pravo, vol. 3, pp. 30-40.

5. Salikhova, O. and Bak, H. (2015), "Rol' inozemnykh tekhnolohij v investytsijno-innovatsijnoi modernizatsii ekonomiky: dosvid Respubliky Koreia, uroky dlia Ukrainy”, Ekonomika i prohnozuvannia, vol. 1, pp. 105-120.

6. Efremov, V. and Vladymyrova, Y. (2017), "Osobennosty transnatsyonalyzatsyy kompanyj Yuzhnoj Korey. Ynnovatsyy y ynvestytsyy", vol. 2, pp. 27-34.

7. The official site of International Monetary Fund (2019), "IMF Staff Reports for the G-20 Mutual Assessment Process", available at: http://www.imf.org/external/np/g20/pdf/110411.pdf (accessed: 1 November 2019).

8. The official site of United Nations Conference on Trade and Development (2019) "Investment and Technology Policies for Competitiveness: Review of Successful Country Experiences", available at: https://unctad.org/en/Docs/iteipc20032_en.pdf (accessed: 5 November 2019).

9. Vox Ukraine (2019) “Pivdenna Koreya: spravzhni prychyny hrandioznoho zrostannya”, available at: https://voxukraine.org/ uk/pivdenna-koreya-spravzhni-prichini-grandioznogo-zrostannya (accessed: 11 November 2019). 
10. The official site of United Nations (2019) "Undata the world of information", available at: http://data.un.org (accessed: 13 November 2019).

11. The official site of Samsung (2019), available at: https://www.samsung.com/us/aboutsamsung/home (accessed: 12 November 2019).

12. The official site of Samsung Heavy Industries http://www.samsungshi.com/Eng/Company/info_overview.aspx (accessed: 15 November 2019).

Zainchkovska Marharyta, Korohodova Olena National Technical University of Ukraine "Igor Sikorsky Kyiv Polytechnic Institute"

\section{THE INFLUENCE OF TRANSNATIONAL COMPANIES ON THE EMERGENCY ECONOMIES DEVELOPMENT (ON THE REPUBLIC OF KOREA EXAMPLE)}

The contribution of large multinational companies to the development of emergent countries is considered in the article. Attention is paid to the peculiarities and differences of transnational companies that have developed in emergent economies. The example of the Republic of Korea shows how much TNCs influence the development and specialization of the economy of the country of origin. Attention is drawn to the factors that make the Republic of Korea such a significant level of economic development. The importance and significance of such factors as the type of economy of the Republic of Korea and the socio-psychological characteristics of Koreans are noted. The course and dynamics of the economic development of the Republic of Korea are analyzed. The "Korean" type of multinational corporation bee was considered. The historical and economic prerequisites for the emergence of chaebol are considered. Their path of development and periods of growth and decline are explored. The role of bees in the "economic miracle" of the Republic of Korea has been identified and shown. The study considered: the path of development, scope and impact on the global economy of the largest TNCs of the Republic of Korea - Samsung. Consideration has been given to changing Samsung's specialization since 1938, when the company began as a rice trader, ending today. The main stages of development are covered and the current state of this TNC is evaluated. All available business areas of Samsung were covered. The factors that have made Samsung such a successful and diversified corporation have been considered and identified. As a result of the analysis, the main reasons for the rapid economic growth of the Republic of Korea were identified. The importance of individual factors in the economic growth of the Republic of Korea is revealed. The specialization of emergent countries is investigated. The main features and differences of emergent economies and companies operating in the territories of such countries are summarized.

Key words: emergent countries, TNCs, transnational corporations, bees, Republic of Korea.

JEL classification: F23, P47, P52. 